\title{
Inoculation of corn silage with Lactobacillus plantarum and Bacillus subtilis associated with amylolytic enzyme supply at feeding. 1. Feed intake, apparent digestibility, and microbial protein synthesis in wethers
}

\author{
Erika C. Lara*, Uly C. Bragiato, Carlos H.S. Rabelo, Juliana D. Messana, \\ Ricardo A. Reis \\ UNESP, São Paulo State University, Department of Animal Sciences, 14884-900, Jaboticabal, SP, Brazil
}

\section{A R T I C L E I N F O}

\section{Keywords:}

Amylase

Bacterial inoculant

Digestibility

Ruminal fermentation

Starch

\begin{abstract}
A B S T R A C T
The current study aimed to investigate the effects of corn silage inoculation and dietary supplementation with amylolytic enzymes, and their interactions, on feed intake, apparent digestibility, and microbial protein synthesis in wethers. Whole-crop corn forage was ensiled either with water (untreated) or with Lactobacillus plantarum MA $18 / 5 \mathrm{U}$ at $1 \times 10^{5} \mathrm{cfu} / \mathrm{g}$ fresh forage combined with Bacillus subtilis AT553098 at $1 \times 10^{5} \mathrm{cfu} / \mathrm{g}$ fresh forage (inoculated). Eight ruminally cannulated Dorper $\times$ Santa Inês crossbred wethers were used in a double $4 \times 4$ Latin square design. Wethers were assigned to one of four diets, as follows: 1) untreated corn silage with no amylolytic enzyme supply (US-NE); 2) untreated corn silage with amylolytic enzyme supply (US-WE); 3) inoculated corn silage with no amylolytic enzyme supply (IS-NE); and 4) inoculated corn silage with amylolytic enzyme supply (IS-WE). $\alpha$-Amylase (602 dextrinizing units/kg of dry matter (DM)) was supplied to the wethers at total mixed ration delivery. Dietary supplementation with amylolytic enzyme increased $(P=0.045) \mathrm{DM}$ and starch $(P=0.014)$ intake in wethers fed the US diet ( +245 and $+136 \mathrm{~g} / \mathrm{d}$, respectively), but not in those fed the IS diet. Inoculation of corn silage $(P=0.026)$ improved organic matter $(\mathrm{OM})$, crude protein (CP), neutral detergent fiber (aNDFom), and gross energy (GE) digestibility by $5.3 \%, 11.5 \%, 25.8 \%$, and $7.1 \%$, respectively. Likewise, enzyme supply increased $(P=0.042)$ the apparent digestibility of DM, OM, CP, aNDFom, and GE by $5.1 \%, 4.7 \%, 9.4 \%, 20.7 \%$, and $6.2 \%$, respectively. Enzyme supply increased the molar proportion of propionic acid $(P=0.002 ; 24.1 \mathrm{vs} .19 .6 \mathrm{mM} /$ $100 \mathrm{mM}$ ) in wethers fed the US diet, but not in those fed the IS diet. Enzyme supply decreased microbial $\mathrm{N}$ synthesis $(P=0.025 ; 6.33$ vs. $8.05 \mathrm{~g} / \mathrm{d})$ when the wethers were fed the IS diet, but not the US diet. In conclusion, despite the improved OM digestibility, dietary supplementation
\end{abstract}

\footnotetext{
Abbreviations: ADFom, acid detergent fiber expressed exclusive of residual ash; aNDFom, neutral detergent fiber assayed with a heat stable amylase and expressed exclusive of residual ash; AP, absorbed purine; CFU, colony-forming units; CHOT, total carbohydrates; CP, crude protein; DE, digestible energy; DM, dry matter; DMI, dry matter intake; DOMR, digestible organic matter fermented in the rumen; DU, dextrinizing unit; EE, ether extract; EMNS, efficiency of microbial N synthesis; GE, gross energy; ME, metabolized energy; NFC, non-fiber carbohydrates; OM, organic matter; PD, purine derivate; TMR, total mixed ration; TN, total nitrogen; VFA, volatile fatty acid

* Corresponding author at: Departamento de Zootecnia, Universidade Estadual Paulista (UNESP), Via de acesso Prof. Paulo Donato Castellane, km5, 14884-900, Jaboticabal, SP, Brazil.

E-mail address: erika.lara@agroceres.com (E.C. Lara).
} 
with amylolytic enzyme yielded inconsistent results with respect to feed intake and microbial protein synthesis in wethers fed diets differing in the use of silage inoculant.

\section{Introduction}

Livestock production has become intensive worldwide, and using a high-grain based diet is a common practice to increase animal performance in this system. Thus, dietary supplementation with enzymes such as $\alpha$-amylase has been examined as a direct-feed additive to enhance feed utilization, so that the higher nutrient demands of ever-increasing animal productivity can be met (Rode et al., 2001; Tricarico et al., 2008). In this regard, enhanced dry matter intake (DMI) has been reported in long-term studies on beef cattle and dairy cows fed diets supplied with an amylolytic enzyme (Klingerman et al., 2009; Tricarico et al., 2007), but not in shortterm studies with lambs (Rojo et al., 2005). Enhanced DMI likely arises from improvements in the apparent total-tract digestibility of organic matter (OM) (Rojo et al., 2005), even in cases where starch digestibility was not improved (Klingerman et al., 2009). Increased molar proportion of propionate has also been observed in small and large ruminants fed diets supplied with amylolytic enzymes, despite the inconsistent results observed depending on the dietary composition and enzyme dosage (Nozière et al., 2014; Rojo et al., 2005). In this context, increased DMI and OM digestibility may provide higher energy and N uptake into the rumen, which in theory may support a better N balance (Schuba et al., 2017) and higher microbial protein synthesis (Clark et al., 1992). However, to the best of our knowledge, few studies have investigated the effects of dietary supplementation with an amylolytic enzyme on the $\mathrm{N}$ balance and microbial protein synthesis. For instance, increasing dietary doses of an Aspergillus oryzae extract with $\alpha$-amylase activity did not alter the $\mathrm{N}$ balance or microbial protein synthesis of lactating dairy cows (Takiya et al., 2017).

Furthermore, in some intensive systems of livestock production, corn silage has been the primary source of fiber (Bernardes and Rêgo, 2014; Oliveira and Millen, 2014). In this regard, silage inoculants containing bacteria such as Lactobacillus plantarum are used to rapidly reduce silage $\mathrm{pH}$, avoiding the proliferation of undesired microorganisms during fermentation, with consequent improvements of silage quality (Oliveira et al., 2017). Additionally, two studies suggested that Bacillus subtilis (an endospore-forming bacterium) might be used alone (Basso et al., 2012) or combined with L. plantarum (Lara et al., 2016) to increase acetic acid content and aerobic stability (by suppressing yeasts growth), with gains in OM digestibility of corn silage. However, no study has previously been carried out to assess the interaction between inoculation and amylolytic enzyme supply and their effects on feed utilization by ruminants.

It was hypothesized that both inoculation of corn silage and dietary supplementation with amylolytic enzyme could be used to manipulate and improve feed utilization. Thus, our study was designed to investigate the effects of corn silage inoculation and dietary supplementation with amylolytic enzyme, and their interaction, on feed intake, apparent digestibility, and microbial protein synthesis in wethers.

\section{Material and methods}

\subsection{Ethics statement}

Animal care and handling procedures were carried out in accordance with the Brazilian College of Animal Experimentation (COBEA) guidelines and were approved by the Ethics, Bioethics, and Animal Welfare Committee (CEBEA) of the FCAV/UNESPJaboticabal campus, Brazil (protocol no. 1.754/15).

\subsection{Crop harvest and silage preparation}

A flint corn (hybrid 2B710, Dow AgroSciences Cravinhos, SP, Brazil) was planted on December 18, 2013, at the São Paulo State University ( $21^{\circ} 15^{\prime} \mathrm{S}$ and $48^{\circ} 18^{\prime} \mathrm{W}$; altitude: $605 \mathrm{~m}$; Jaboticabal, SP, Brazil). On March 24, 2014 (97 d after planting), whole-crop corn was harvested in random locations throughout the field at approximately $344 \mathrm{~g} / \mathrm{kg}$ dry matter (DM), at a stubble height of $20 \mathrm{~cm}$, using a pull-type $\mathrm{JF} 90^{\circledR}$ forage harvester (JF Agricultural Machinery, Itapira, SP, Brazil). Forage was cut to $10 \mathrm{~mm}$; kernels were not processed. Thereafter, chopped forages were tractor loaded for delivery to the stack silos. Corn forage was then treated either with water ( $2 \mathrm{~L} / \mathrm{t}$; untreated) or with Lactobacillus plantarum MA 18/5U at $1 \times 10^{5}$ colony forming units (cfu)/g fresh forage (Lallemand Animal Nutrition, Goiânia, GO, Brazil) combined with Bacillus subtilis AT553098 at $1 \times 10^{5} \mathrm{cfu} / \mathrm{g}$ fresh forage (inoculated; Fatec Animal Nutrition and Health, Arujá, SP, Brazil). In order to ensure homogeneous distribution of the inoculant over the crop, while the corn forage was spread and packed, the inoculant was dissolved in distilled water $(2 \mathrm{~L} / \mathrm{t})$ and sprayed onto fresh forage layer by layer as silos were filled by using a sterilized costal pomp (Basso et al., 2014; Mohammadzadeh et al., 2012). The application level was verified by dilution plating on Man, Rogosa, and Sharpe agar (MRS, Oxoid Ltd., Unipath, Basingstoke, UK) and it was determined in accordance with previous studies carried out in our laboratory (Basso et al., 2012, 2014; Lara et al., 2016).

Two stack silos $(n=1)$ were each filled with approximately 20 tons corn forage (fresh matter) in two consecutive days. To avoid possible cross-contamination, untreated forage was ensiled first, followed by inoculated forage. Forage was packed by a Wheel launder (Cat ${ }^{\circledast}$, Peoria, Chicago, USA), and the bulk density of the silos was calculated to be, on average, $580 \mathrm{~kg}$ fresh forage $/ \mathrm{m}^{3}$ by the end of filling. Silos were sealed with black-on-white polyethylene film (thickness $=200 \mu \mathrm{m}$; Electro Plastic, São Paulo, SP, Brazil), 
and were stored in the field (ambient temperature $=22.1 \pm 2.5^{\circ} \mathrm{C}$ ) for $170 \mathrm{~d}$. The plastic covering was weighted with soil to ensure close contact between covering and surface of the silage. Ten fresh samples $(\sim 300 \mathrm{~g})$ of corn forage were collected from each silo during filling and stored at $-20^{\circ} \mathrm{C}$ until further analyses.

\subsection{Animal management and feeding}

After silos were opened, the silages described above were used to formulate four total mixed rations (TMR) daily, as follows: 1) untreated corn silage with no amylolytic enzyme added (US-NE); 2) untreated corn silage with amylolytic enzyme added (US-WE); 3) inoculated corn silage with no amylolytic enzyme added (IS-NE); and 4) inoculated corn silage with amylolytic enzyme added (ISWE). Diets were composed of $400 \mathrm{~g} / \mathrm{kg}$ respective corn silage and $600 \mathrm{~g} / \mathrm{kg}$ concentrate on a DM basis (Table 1) and were balanced to meet the nutrient requirements of wethers gaining $300 \mathrm{~g} / \mathrm{d}$ (NRC, 2007). Feed ingredients (silage and concentrate) used to formulate TMR were sampled twice a week for DM determination and chemical analyses. Silage was obtained by sampling from six locations from the feeding face of each silo (two each from the lower and upper areas and two from the center area) and bulked into a single sample on each sampling day. Samples for chemical analyses were processed to form composite samples $(n=10)$ for each of the four 16-d periods during which wethers were fed experimental diets, and were stored at $-20^{\circ} \mathrm{C}$ until further analyses. The DM of ingredients measured weekly was used to adjust the proportion of ingredients in the TMR.

A powdered concentrate from A. oryzae (Amaize, Alltech Inc.) containing primarily $\alpha$-amylase activity was used in the current study. The $\alpha$-amylase activity was determined according to the procedure described in the Food Chemicals Codex (1996). One $\alpha$ amylase dextrinizing unit (DU) was defined as the quantity of enzyme required to dextrinize soluble starch at the rate of $1 \mathrm{~g} / \mathrm{h}$ at $30{ }^{\circ} \mathrm{C}$ and $\mathrm{pH}$ 4.8. The preparation used in the current study contained $301 \mathrm{DU} / \mathrm{g}$ of product. This preparation was added to TMR, under constant mixing by hand, immediately at the time of feeding delivery at a rate of $2 \mathrm{~g} / \mathrm{kg} \mathrm{DM}$. The final concentration of $\alpha$-amylase fed to the wethers was then $602 \mathrm{DU} / \mathrm{kg} \mathrm{DM}$.

Eight ruminally cannulated Dorper $\times$ Santa Inês crossbred wethers (initial body weight $=37.4 \pm 2.2 \mathrm{~kg}$; age $=6$ months), each fitted with a 64-mm silicone ruminal cannula, were used in a double $4 \times 4$ Latin square design. Each wether was housed individually in a $1.2 \times 0.5 \mathrm{~m}$ metabolism crate equipped with a feed bunk and a water bowl, and also with feces and urine collectors. Each wether

Table 1

Ingredient proportions and chemical composition of the total mixed rations containing corn silage untreated or inoculated with Lactobacillus plantarum and Bacillus subtilis ${ }^{\mathrm{a}}$ (data are given in $\mathrm{g} / \mathrm{kg}$ DM, unless otherwise stated).

\begin{tabular}{lll}
\hline Item & Untreated & Inoculated \\
\hline Ingredient proportion & & \\
Corn silage & 400 & 400 \\
Ground corn & 480 & 480 \\
Urea & 12.0 & 12.0 \\
Soybean meal & 84.0 & 84.0 \\
Commercial premix ${ }^{\mathrm{b}}$ & 24.0 & 24.0 \\
Chemical composition & & \\
DM & & 675 \\
OM & 669 & 948 \\
CP & 943 & 150 \\
EE & 151 & 20.0 \\
CHOT & 21.0 & 778 \\
aNDFom & 771 & 258 \\
ADFom & 257 & 126 \\
Lignin (sa) & 126 & 12.0 \\
Starch & 13.0 & 363 \\
NFC & 371 & 520 \\
ME, MJ/kg DM & 514 & 10.5 \\
\hline
\end{tabular}

a Whole-crop corn forage was treated at ensiling either with distilled water ( $2 \mathrm{~L} / \mathrm{t}$; untreated) or with Lactobacillus plantarum MA $18 / 5 \mathrm{U}$ at $1 \times 10^{5} \mathrm{cfu} / \mathrm{g}$ fresh forage (Lallemand Animal Nutrition, Goiânia, GO, Brazil) and Bacillus subtilis AT553098 at $1 \times 10^{5} \mathrm{cfu} / \mathrm{g}$ fresh forage (inoculated; Fatec Animal Nutrition and Health, Arujá, SP, Brazil).

b Commercial premix was composed (on a DM basis) of: $7.0 \mathrm{~g} / \mathrm{kg} \mathrm{NaCl} ; 7.0 \mathrm{~g} / \mathrm{kg}$ phosphate; $25.6 \mathrm{~g} / \mathrm{kg}$ limestone; $12 \mathrm{~g} / \mathrm{kg} \mathrm{Ca} ; 4.0 \mathrm{~g} / \mathrm{kg} \mathrm{P} ; 2.85 \mathrm{~g} / \mathrm{kg} \mathrm{Na} ; 4.49 \mathrm{~g} / \mathrm{kg} \mathrm{Cl} ; 6.35 \mathrm{~g} / \mathrm{kg} \mathrm{K} ; 1.44 \mathrm{~g} / \mathrm{kg}$ $\mathrm{Mg} ; 1.79 \mathrm{~g} / \mathrm{kg} \mathrm{S} ; 131 \mathrm{mg} / \mathrm{kg}$ Fe; $0.78 \mathrm{mg} / \mathrm{kg} \mathrm{Co} ; 0.42 \mathrm{mg} / \mathrm{kg} \mathrm{Se} ; 42 \mathrm{mg} / \mathrm{kg}$ vitamin E; 5799 UI vitamin A; and 501 UI vitamin D3.

c $\mathrm{DM}=$ dry matter; $\mathrm{OM}=$ organic matter; $\mathrm{CP}=$ crude protein; $\mathrm{EE}=$ ether extract; $\mathrm{CHOT}=$ total carbohydrates; aNDFom = neutral detergent fiber assayed with a heat stable amylase and expressed exclusive of residual ash; ADFom = acid detergent fiber expressed exclusive of residual ash; NFC = non-fiber carbohydrates; ME = metabolized energy (calculated as total apparent digestibility of gross energy $\times 0.82$ ). 
was randomly assigned to one of four diets described above, and they were fed once a day (07:00) ad libitum (producing approximately $10 \%$ orts), with free access to drinking water. The trial was carried out over four consecutive 16-d periods with no interval between them. A $10 \mathrm{~d}$ period was allocated for the wethers to adapt to the diets based on previous studies assessing the growth performance of large and small ruminants fed inoculated silage in our laboratory (Basso et al., 2014; Rabelo et al., 2016a). The latter six days of each period were used for measurements of feed intake, apparent digestibility, microbial protein synthesis and $\mathrm{N}$ balance, and ruminal fermentation.

\subsection{Measurement of feed intake, apparent digestibility, microbial protein synthesis, and $N$ balance}

Feed intake and apparent digestibility were measured on days 11-15 of each period. Orts were weighed daily before morning feeding to calculate DMI and the chemical composition was also taken in consideration to calculate apparent digestibility. Samples of silage, concentrate, orts, and feces were also collected daily. Samples were composited across the $5 \mathrm{~d}$ period for chemical analyses and were stored at $-20^{\circ} \mathrm{C}$ before analysis.

On days 11-15 of each period, total urine produced daily was collected in plastic vessels placed below the urine outlet in the metabolism crates containing $100 \mathrm{ml}$ of sulfuric acid solution (1:0.1 v/v). Sulfuric acid solution was used to maintain the final pH below 3.0. After each $24 \mathrm{~h}$ collection period, the total weight and volume of urine excreted were determined, and thereafter, samples were composited across the $5 \mathrm{~d}$ period. These samples were used to determine urinary- $\mathrm{N}$. In addition, a $10 \mathrm{ml}$ sample of urine was collected and diluted with $40 \mathrm{ml}$ of a $0.036 \mathrm{~N} \mathrm{H}_{2} \mathrm{SO}_{4}$ in an acid: urine ratio of $4: 1 \mathrm{v} / \mathrm{v}$, and stored at $-20{ }^{\circ} \mathrm{C}$ for later analysis of purine derivatives (PD).

\subsection{Ruminal fermentation}

On day 16 of each period, a $50 \mathrm{ml}$ sample of ruminal fluid was collected from each wether before feeding $(0 \mathrm{~h})$, and at 3,6 , 9 , and $12 \mathrm{~h}$ post feeding. Ruminal fluid was squeezed through four layers of cheesecloth, and $\mathrm{pH}$ was immediately measured using a pH meter (model MA522, Marconi Laboratory Equipment, Piracicaba, SP, Brazil). To inhibit microbial activity, $1 \mathrm{ml}_{2} \mathrm{SO}_{4} \mathrm{diluted}_{\text {with }}$ distilled water $(1: 1 \mathrm{v} / \mathrm{v})$ was added to the ruminal fluid $(50 \mathrm{~mL})$ in an acid: rumen fluid ratio of $0.01: 1 \mathrm{v} / \mathrm{v}$. The resulting solution was stored at $-20{ }^{\circ} \mathrm{C}$ until volatile fatty acid (VFA) and ammonia-N analyses could be carried out.

\subsection{Microbial analyses of silages}

Fresh silage samples ( $25 \mathrm{~g}$ ) from each replicate were homogenized in $225 \mathrm{ml}$ autoclaved saline solution $(0.85 \% \mathrm{NaCl})$ and the mixture was manually agitated for $1 \mathrm{~min}$. An aliquot $(1 \mathrm{~mL})$ of this solution was transferred into tubes containing $9 \mathrm{ml}$ saline solution; $1 \mathrm{ml}$ of the resulting mixture was plated onto Petri plates after serial dilutions of $10^{-1}-10^{-9}$. The MRS agar was used to count lacticacid bacteria by pour plate, whereas potato dextrose agar (PDA) was used to count yeasts and molds by spread-plate. Both MRS and PDA plates were incubated at $28^{\circ} \mathrm{C}$ according to protocols used in previous studies carried out in our laboratory (Basso et al., 2012; Lara et al., 2016; Rabelo et al., 2017). Lactic acid bacteria and yeasts were counted after 2 d, and molds were counted after 5 d. All microbiological data were $\log _{10}$-transformed before analysis.

\subsection{Chemical analyses}

To measure fermentation end products of silages, $25 \mathrm{~g}$ of fresh silage was mixed with $225 \mathrm{ml}$ of distilled water. This mixture was blended in a Phillips Walita blender (Walita, Varginha, MG, Brazil) for $1 \mathrm{~min}$ at the highest setting, and filtered through two layers of cheesecloth. The $\mathrm{pH}$ of the filtrate was measured immediately using a pH meter (model MA522, Marconi Laboratory Equipment, Piracicaba, SP, Brazil). Ammonia-N was measured by distillation (AOAC, 1996; method no. 941.04) and expressed as g/kg total N (TN). Lactic acid was determined by a colorimetric method (Pryce, 1969). Volatile fatty acids were measured using a gas chromatograph (Shimadzu model GC2014, Shimadzu Corp., Kyoto, Japan) equipped with a capillary column (HP-INNOWax $30 \mathrm{~m} \times 0.32 \mathrm{~mm}$; Agilent Technologies, Colorado, USA) set at an initial temperature of $80^{\circ} \mathrm{C}$ for 3 min, followed by heating at a rate of $20^{\circ} \mathrm{C} / \mathrm{min}$ until a final temperature of $240^{\circ} \mathrm{C}$ was reached. We followed the same procedures described above about sample preparation and analyses to measure $\mathrm{pH}$ and ammonia- $\mathrm{N}$ of the fresh forage before ensiling.

Samples of forage and silage from the stack silos, and samples of feed ingredients, orts and feces from the feeding experiment were oven-dried at $55^{\circ} \mathrm{C}$ for $72 \mathrm{~h}$ and processed in a knife mill (Wiley mill model 4; Arthur H. Thomas Company, Philadelphia, PA) before being ground through a $1 \mathrm{~mm}$ screen and analyzed for DM $\left(105^{\circ} \mathrm{C}\right.$ for $\left.12 \mathrm{~h}\right)$ and ash $\left(500{ }^{\circ} \mathrm{C}\right.$ for $\left.5 \mathrm{~h}\right)$ content according to methods specified by the AOAC (1996. The OM $(\mathrm{g} / \mathrm{kg}$ ) was calculated as 1000 - ash. Ether extract (EE) was determined according to the procedures described by the AOAC (1996. The TN was measured by rapid combustion using a LECO analyzer (model F528 N, LECO Corp., St. Joseph, MI, USA), and crude protein (CP) was calculated as TN $\times 6.25$. Neutral detergent fiber (aNDFom) and acid detergent fiber (ADFom) levels were measured using the 'Ankom F57' filter bag in a fiber analyzer (ANKOM 2000, ANKOM Technologies, Macedon, NY, USA) following the procedures described by Mertens (2002) and the AOAC (1996, respectively. The aNDFom was measured using a heat-stable amylase without sodium sulfite; both aNDFom and ADFom were expressed exclusive of residual ash. Lignin (sa) was sequentially measured after hydrolysis of the $\mathrm{ADF}$ residual in $72 \% \mathrm{H}_{2} \mathrm{SO}_{4}$ (van Soest and Robertson, 1985). Starch was determined enzymatically (Bach Knudsen et al., 1987). Total carbohydrate and non-fiber carbohydrate (NFC) values were estimated according to the methods described by Sniffen et al. (1992) and Detmann and Valadares Filho (2010), respectively. Gross 
energy (GE) was determined with a bomb calorimeter (PARR 6200; Parr Instrument Company, Milone, IL). The metabolizable energy (ME) was estimated as digestible energy $(\mathrm{DE}) \times 0.82(\mathrm{NRC}, 1985)$.

Aliquots of strained ruminal fluid were thawed in a refrigerator overnight and centrifuged at $20,000 \times g$ for $30 \mathrm{~min}$ at $4{ }^{\circ} \mathrm{C}$. The supernatant was analyzed for VFA using gas chromatography according to the protocols described above. Ruminal ammonia-N was determined by distillation with $2 \mathrm{~N} \mathrm{KOH} \mathrm{(Fenner,} \mathrm{1965).}$

The PD was measured as the sum of allantoin, uric acid, xanthine, and hypoxanthine (Chen and Gomes, 1995), and then daily microbial $\mathrm{N}$ supply was calculated.

\subsection{Calculations}

The daily PD was used to calculate microbial purines absorbed (AP, mmol/d) using the Eq. (1), whereas the microbial $\mathrm{N}$ supply (Eq. (2)) were estimated according to Chen and Gomes (1995):

$$
\text { Daily PD }(\mathrm{mmol} / \mathrm{d})=0.84 \times \mathrm{AP}+\left[0.150 \times \mathrm{BW}^{0.75 \times \exp (-0.25 \mathrm{AP})}\right]
$$

where 0.84 is the recovery of absorbed purines as PD in urine; and the component within parenthesis represents the endogenous contribution, which decreases as exogenous purines become available for utilization by the animal.

$$
\text { Microbial N }(\mathrm{g} \mathrm{N} / \mathrm{d})=(\mathrm{AP} \times 70) /(0.116 \times 0.83 \times 1000)=0.727 \times \mathrm{AP}
$$

where the $\mathrm{N}$ content of purines is $70 \mathrm{mg} \mathrm{N} / \mathrm{mmol}$, the ratio of purine- $\mathrm{N}$ : total $\mathrm{N}$ in mixed ruminal microbes is taken as $11.6: 100$, and the digestibility of microbial purines is assumed to be 0.83 .

The efficiency of microbial $\mathrm{N}$ synthesis (EMNS) was expressed as grams of microbial $\mathrm{N}$ per kilogram of digestible OM fermented in the rumen (DOMR; calculated as OM intake $\times$ OM digestibility $\times 0.65$, according to ARC (1984)).

The $\mathrm{N}$ retention and absorption $(\mathrm{g} / \mathrm{d})$ were calculated according to the Eqs. (3) and (4), as follows:

$$
\begin{aligned}
& \mathrm{N} \text { retained }(\mathrm{g} / \mathrm{d})=\mathrm{N} \text { intake }(\mathrm{g} / \mathrm{d})-[\mathrm{N} \text { fecal }(\mathrm{g} / \mathrm{d})+\mathrm{N} \text { urinary }(\mathrm{g} / \mathrm{d})] \\
& \mathrm{N} \text { absorbed }(\mathrm{g} / \mathrm{d})=\mathrm{N} \text { intake }(\mathrm{g} / \mathrm{d})-\mathrm{N} \text { fecal }(\mathrm{g} / \mathrm{d})
\end{aligned}
$$

\subsection{Statistical analyses}

Statistical analyses of silage data were precluded because there was only one stack silo replicate for each treatment. Data of feed intake, apparent digestibility, microbial protein synthesis and $\mathrm{N}$ balance were analyzed in a double $4 \times 4$ Latin square design under a $2 \times 2$ factorial arrangement, and ruminal fermentation (i.e., $\mathrm{pH}$, ammonia- $\mathrm{N}$, and VFA) were analyzed as repeated measures over time. All variables were analyzed using the MIXED procedure in SAS software (v. 9.0; SAS Institute Inc., Cary, NC, USA). Several covariance structures (Heterogeneous Autoregressive, Autoregressive Moving Average, and Banded) were tested and those that generated the lowest Akaike information criterion values were selected. Diet was considered a fixed effect, and wethers and period were considered as random effects. Data of feed intake, apparent digestibility, microbial protein synthesis, and $\mathrm{N}$ balance were analyzed using the following general model:

$$
Y_{i j k l m}=\mu+s_{i}+p_{j}+a_{k(i)}+E_{l}+I_{m}+E I_{l m}+e_{i j k l m}
$$

where $Y_{i j k l m}=$ response variable; $\mu=$ overall mean; $s=$ effect of Latin square $i ; p=$ effect of experimental period $j ; a=$ effect of animal $k$ within the Latin square $i ; E=$ effect of enzyme $l ; I=$ effect of inoculant $m ; E I=$ effect of interaction between enzyme $l$ and inoculant $m$; and $e_{i j k l m}=$ error term.

Data of ruminal fermentation were analyzed using the following general model:

$$
Y_{i j k l m n}=\mu+s_{i}+p_{j}+a_{k(i)}+E_{l}+I_{m}+E I_{l m}+T_{n}+E I T_{l m n}+e_{i j k l m n}
$$

where $Y_{i j k l m n}=$ response variable; $\mu=$ overall mean; $s=$ effect of Latin square $i ; p=$ effect of experimental period $j ; a=$ effect of animal $k$ within the Latin square $i ; E=$ effect of enzyme $l ; I=$ effect of inoculant $m$; $E I=$ effect of interaction between enzyme $l$ and inoculant $m ; T=$ effect of sampling time $n ; E I T=$ effect of interaction among enzyme $l$, inoculant $m$ and sampling time $n$; and $e_{i j k l m}=$ error term.

Homogeneity of the data was verified using the UNIVARIATE procedure of SAS (v. 9.0; SAS Institute Inc., Cary, NC). Studentized residuals were plotted against the predicted values using the plot procedure to analyze data for outliers. Differences between means for each factor examined (i.e., inoculation and enzyme supply) and their significant interactions were determined using the PDIFF option of LSMEANS in SAS software, which is based on Fisher's $F$-protected least significant difference test. Significant differences were declared in cases where $P \leq 0.05$, and the discussion of trends was considered in cases where $0.05<P \leq 0.10$. 


\section{Results}

\subsection{Fermentation and chemical composition of corn silage}

Inoculation of whole-crop corn silage slightly increased lactic acid and NFC content, while it reduced propionic acid content and the yeast count (Table 2).

\subsection{Feed intake and apparent digestibility of wethers}

There was an interaction between inoculation and enzyme supply $(P=0.045)$ for DMI, in which enzyme supply increased DMI in wethers fed the US diet $(+245 \mathrm{~g} / \mathrm{d})$, but not those fed the IS diet (Table 3$)$. Likewise, enzyme supply increased starch intake $(P=$ $0.014)$ only for wethers fed the US diet $(+136 \mathrm{~g} / \mathrm{d})$. Moreover, there was a trend $(P=0.089)$ towards enzyme supply increasing OM, aNDFom, GE, DE, and ME intake when the wethers were fed the US diet, but not when they were fed the IS diet.

Inoculation of corn silage increased the coefficients of OM apparent digestibility $(P=0.026 ; 787 \mathrm{~g} / \mathrm{kg} \mathrm{vs} .748 \mathrm{~g} / \mathrm{kg}), \mathrm{CP}(P=$ $0.001 ; 744 \mathrm{~g} / \mathrm{kg}$ vs. $667 \mathrm{~g} / \mathrm{kg})$, aNDFom $(P=0.001 ; 546 \mathrm{~g} / \mathrm{kg}$ vs. $434 \mathrm{~g} / \mathrm{kg})$, and GE $(P=0.011 ; 759 \mathrm{~g} / \mathrm{kg}$ vs. $709 \mathrm{~g} / \mathrm{kg})$ when compared with the US diet (Table 3$)$. Furthermore, enzyme supply increased the apparent digestibility of DM $(P=0.024 ; 723 \mathrm{~g} / \mathrm{kg}$ vs. $760 \mathrm{~g} / \mathrm{kg}), \mathrm{OM}(P=0.042 ; 750 \mathrm{~g} / \mathrm{kg}$ vs. $785 \mathrm{~g} / \mathrm{kg}), \mathrm{CP}(P=0.005 ; 674 \mathrm{~g} / \mathrm{kg}$ vs. $737 \mathrm{~g} / \mathrm{kg}), \mathrm{aNDFom}(P=0.020 ; 444 \mathrm{~g} / \mathrm{kg}$ vs. $536 \mathrm{~g} / \mathrm{kg})$, and GE ( $P=0.022 ; 712 \mathrm{~g} / \mathrm{kg}$ vs. $756 \mathrm{~g} / \mathrm{kg})$ in comparison with wethers fed the NE diet.

\subsection{Ruminal fermentation}

There was an interaction between inoculation and enzyme supply for the molar proportion of acetic acid, in which inoculation of corn silage increased it $(P=0.047)$ only when wethers were fed the WE diet (Table 4$)$. Additionally, the molar proportion of

Table 2

Fermentation and chemical composition (mean \pm standard error of the mean) of whole-crop corn silage either untreated or inoculated with Lactobacillus plantarum and Bacillus subtilis, after $170 \mathrm{~d}$ of ensilage in stack silos (data are given in $\mathrm{g} / \mathrm{kg} \mathrm{DM}$, unless otherwise stated, and represents the mean and standard deviation obtained during silos unloading period).

\begin{tabular}{|c|c|c|c|}
\hline \multirow[t]{2}{*}{ Item } & \multirow[t]{2}{*}{ Corn plant } & \multicolumn{2}{|l|}{ Corn silage $^{\mathrm{a}}$} \\
\hline & & Untreated & Inoculated \\
\hline \multicolumn{4}{|l|}{ Fermentation profile } \\
\hline Lactic acid & NA & $15.1 \pm 1.69$ & $21.8 \pm 2.10$ \\
\hline Acetic acid & NA & $14.2 \pm 0.62$ & $12.8 \pm 0.84$ \\
\hline Propionic acid & NA & $1.10 \pm 0.12$ & $0.30 \pm 0.04$ \\
\hline Lactic: acetic ratio & NA & $1.10 \pm 0.18$ & $2.00 \pm 0.15$ \\
\hline $\mathrm{pH}$ & - & $3.86 \pm 0.03$ & $3.74 \pm 0.04$ \\
\hline Ammonia-N, g/kg TN ${ }^{\mathrm{b}}$ & $37.5 \pm 5.13$ & $44.0 \pm 2.98$ & $54.0 \pm 4.32$ \\
\hline \multicolumn{4}{|c|}{ Microbiological profile, $\mathrm{cfu} / \mathrm{g}$ fresh silage } \\
\hline Lactic acid bacteria & $\mathrm{NM}$ & $6.00 \pm 0.13$ & $5.99 \pm 0.09$ \\
\hline Yeasts & $5.42 \pm 0.14$ & $6.35 \pm 0.48$ & $5.78 \pm 0.46$ \\
\hline Molds & $4.50 \pm 0.17$ & $5.60 \pm 0.20$ & $5.15 \pm 0.10$ \\
\hline $\mathrm{DM}$ & $344 \pm 0.32$ & $330 \pm 3.59$ & $332 \pm 3.25$ \\
\hline $\mathrm{OM}$ & $897 \pm 1.19$ & $951 \pm 3.48$ & $960 \pm 1.73$ \\
\hline $\mathrm{CP}$ & $75.0 \pm 0.85$ & $87.0 \pm 0.54$ & $84.0 \pm 0.51$ \\
\hline $\mathrm{EE}$ & $16.5 \pm 0.45$ & $19.0 \pm 0.99$ & $18.0 \pm 1.00$ \\
\hline СHOT & $875 \pm 2.52$ & $842 \pm 4.07$ & $855 \pm 2.37$ \\
\hline aNDFom & $533 \pm 4.22$ & $480 \pm 8.38$ & $483 \pm 9.19$ \\
\hline ADFom & $238 \pm 2.85$ & $258 \pm 5.05$ & $258 \pm 3.53$ \\
\hline Lignin (sa) & $28.5 \pm 0.94$ & $24.0 \pm 1.53$ & $23.0 \pm 1.19$ \\
\hline Starch & $\mathrm{NM}$ & $238 \pm 1.98$ & $218 \pm 2.05$ \\
\hline NFC & $382 \pm 5.81$ & $378 \pm 10.3$ & $392 \pm 9.29$ \\
\hline GE, MJ/kg DM & NM & $17.0 \pm 0.29$ & $18.0 \pm 0.40$ \\
\hline
\end{tabular}

$\mathrm{NA}=$ not applicable.

$\mathrm{NM}=$ not measured.

${ }^{a}$ Whole-crop corn forage was treated at ensiling either with distilled water (2 L/t; untreated) or with Lactobacillus plantarum MA 18/5U at $1 \times 10^{5} \mathrm{cfu} / \mathrm{g}$ fresh forage (Lallemand Animal Nutrition, Goiânia, GO, Brazil) and Bacillus subtilis AT553098 at $1 \times 10^{5} \mathrm{cfu} / \mathrm{g}$ fresh forage (inoculated; Fatec Animal Nutrition and Health, Arujá, SP, Brazil).

b $\mathrm{TN}=$ total nitrogen; $\mathrm{DM}=$ dry matter; $\mathrm{OM}$ = organic matter; $\mathrm{CP}=$ crude protein; $\mathrm{EE}=$ ether extract; $\mathrm{CHOT}=$ total carbohydrates; aNDFom $=$ neutral detergent fiber assayed with a heat stable amylase and expressed exclusive of residual ash; ADFom $=$ acid detergent fiber expressed exclusive of residual ash; NFC = non-fiber carbohydrates; GE = gross energy. 
Table 3

Feed intake and apparent digestibility in wethers fed diets containing corn silage untreated (US) or inoculated with Lactobacillus plantarum and Bacillus subtilis (IS) associated with (WE) or without amylolytic enzyme (NE) supply at feeding*.

\begin{tabular}{|c|c|c|c|c|c|c|c|c|}
\hline \multirow{2}{*}{$\begin{array}{l}\text { Inoculation }^{\mathrm{a}} \\
\text { Enzyme }^{\mathrm{b}}\end{array}$} & \multicolumn{2}{|l|}{ US } & \multicolumn{2}{|l|}{ IS } & \multirow[t]{2}{*}{ SEM } & \multicolumn{3}{|c|}{$P$-value ${ }^{\mathrm{c}}$} \\
\hline & $\mathrm{NE}$ & WE & $\mathrm{NE}$ & $\mathrm{WE}$ & & I & $\mathrm{E}$ & $\mathrm{I} \times \mathrm{E}$ \\
\hline \multicolumn{9}{|c|}{ Intake of nutrients, $\mathrm{g} / \mathrm{d}$} \\
\hline $\mathrm{DM}^{\mathrm{d}}$ & $1,066^{\mathrm{y}}$ & $1,311^{\mathrm{x}}$ & $1,263^{x y}$ & $1,128^{x y}$ & 0.05 & 0.930 & 0.540 & 0.045 \\
\hline $\mathrm{OM}$ & 1,021 & 1,238 & 1,201 & 1,073 & 43.7 & 0.719 & 0.904 & 0.088 \\
\hline $\mathrm{CP}$ & 183 & 203 & 195 & 175 & 7.15 & 0.665 & 0.850 & 0.114 \\
\hline $\mathrm{EE}$ & 26.0 & 29.0 & 28.0 & 27.0 & 0.86 & 0.869 & 0.486 & 0.179 \\
\hline aNDFom & 275 & 310 & 306 & 268 & 10.7 & 0.787 & 0.936 & 0.074 \\
\hline Starch & $383^{\mathrm{y}}$ & $519^{x}$ & $449^{y}$ & $403^{y}$ & 22.0 & 0.470 & 0.200 & 0.014 \\
\hline GE & 20.0 & 23.0 & 22.0 & 20.0 & 0.81 & 0.702 & 0.924 & 0.089 \\
\hline $\mathrm{DE}, \mathrm{MJ} / \mathrm{kg} \mathrm{DM}$ & 12.8 & 16.6 & 16.1 & 15.2 & 0.65 & 0.467 & 0.289 & 0.088 \\
\hline $\mathrm{ME}, \mathrm{MJ} / \mathrm{kg} \mathrm{DM}$ & 10.5 & 13.6 & 13.2 & 12.5 & 0.53 & 0.467 & 0.289 & 0.088 \\
\hline \multicolumn{9}{|c|}{ Apparent digestibility, $\mathrm{g} / \mathrm{kg}$} \\
\hline $\mathrm{DM}$ & 714 & 741 & 732 & 779 & 9.00 & 0.083 & 0.024 & 0.530 \\
\hline $\mathrm{OM}$ & 737 & 758 & 762 & 812 & 8.00 & 0.026 & 0.042 & 0.388 \\
\hline $\mathrm{CP}$ & 649 & 685 & 698 & 789 & 1.40 & 0.001 & 0.005 & 0.180 \\
\hline $\mathrm{EE}$ & 896 & 897 & 901 & 957 & 1.30 & 0.190 & 0.250 & 0.280 \\
\hline aNDFom & 396 & 471 & 491 & 600 & 2.40 & 0.001 & 0.020 & 0.660 \\
\hline Starch & 967 & 969 & 964 & 969 & 3.00 & 0.770 & 0.500 & 0.830 \\
\hline GE & 689 & 728 & 734 & 783 & 10.0 & 0.011 & 0.022 & 0.782 \\
\hline
\end{tabular}

${ }^{\mathrm{x}-\mathrm{y}}$ Means in the same row with different superscripts differed significantly $(P \leq 0.05)$.

* Measurements were taken on days 11-15 of each period.

${ }^{a}$ Whole-crop corn forage was treated at ensiling either with distilled water (2 L/t; untreated) or with Lactobacillus plantarum MA $18 / 5 \mathrm{U}$ at $1 \times 10^{5} \mathrm{cfu} / \mathrm{g}$ fresh forage (Lallemand Animal Nutrition, Goiânia, GO, Brazil) and Bacillus subtilis AT553098 at $1 \times 10^{5} \mathrm{cfu} / \mathrm{g}$ fresh forage (inoculated; Fatec Animal Nutrition and Health, Arujá, SP, Brazil).

b The $\alpha$-amylase (602 DU/kg DM) was supplied to the wethers at total mixed ration delivery.

${ }^{c} \mathrm{I}=$ inoculation; $\mathrm{E}=$ amylolytic enzyme; $\mathrm{I} \times \mathrm{E}=$ interaction between inoculation and amylolytic enzyme.

${ }^{\mathrm{d}} \mathrm{DM}=$ dry matter; $\mathrm{OM}=$ organic matter; $\mathrm{CP}=$ crude protein; $\mathrm{EE}=$ ether extract; aNDFom = neutral detergent fiber assayed with a heat stable amylase and expressed exclusive of residual ash; $\mathrm{GE}=$ gross energy; $\mathrm{DE}=$ digestible energy; $\mathrm{ME}=$ metabolizable energy.

Table 4

Ruminal fermentation in wethers fed diets containing corn silage untreated (US) or inoculated with Lactobacillus plantarum and Bacillus subtilis (IS) associated with (WE) or without amylolytic enzyme (NE) supply at feeding*.

\begin{tabular}{|c|c|c|c|c|c|c|c|c|c|c|}
\hline \multirow{2}{*}{$\begin{array}{l}\text { Inoculation }^{\mathrm{a}} \\
\text { Enzyme }^{\mathrm{b}}\end{array}$} & \multicolumn{2}{|l|}{ US } & \multicolumn{2}{|l|}{ IS } & \multirow[t]{2}{*}{ SEM } & \multicolumn{5}{|c|}{$P$-value ${ }^{c}$} \\
\hline & $\mathrm{NE}$ & WE & NE & WE & & I & $\mathrm{E}$ & $\mathrm{I} \times \mathrm{E}$ & $\mathrm{T}$ & $\mathrm{I} \times \mathrm{E} \times \mathrm{T}$ \\
\hline $\mathrm{pH}$ & 5.98 & 5.94 & 5.91 & 5.96 & 0.04 & 0.462 & 0.895 & 0.234 & $<0.001$ & 0.352 \\
\hline Ammonia-N, mg/dL & 24.9 & 22.9 & 25.3 & 25.1 & 0.77 & 0.231 & 0.294 & 0.375 & $<0.001$ & 0.145 \\
\hline Total VFA, $\mathrm{mM}^{\mathrm{d}}$ & 78.4 & 79.3 & 71.8 & 78.6 & 1.67 & 0.274 & 0.246 & 0.365 & $<0.001$ & 0.255 \\
\hline \multicolumn{11}{|c|}{ Molar proportion, mM/100 mM } \\
\hline Acetic acid & $68.3^{x y}$ & $65.7^{y}$ & $68.0^{x y}$ & $68.5^{\mathrm{x}}$ & 0.32 & 0.124 & 0.173 & 0.047 & $<0.001$ & 0.953 \\
\hline Propionic acid & $19.6^{\mathrm{y}}$ & $24.1^{\mathrm{x}}$ & $21.2^{\mathrm{xy}}$ & $19.8^{\mathrm{y}}$ & 0.38 & 0.139 & 0.111 & 0.002 & $<0.001$ & 0.995 \\
\hline Butyric acid & 11.2 & 10.2 & 10.9 & 11.6 & 0.14 & 0.094 & 0.923 & 0.133 & $<0.001$ & 0.406 \\
\hline Acetic: propionic ratio & $3.49^{x}$ & $2.79^{\mathrm{y}}$ & $3.30^{x y}$ & $3.56^{\mathrm{x}}$ & 0.08 & 0.083 & 0.183 & 0.005 & $<0.001$ & 0.809 \\
\hline
\end{tabular}

${ }^{\mathrm{x}-\mathrm{y}}$ Means in the same row with different superscripts differed significantly $(P \leq 0.05)$.

* Measurements were taken on day 16 of each period at $0,3,6,9$, and $12 \mathrm{~h}$ post-feeding.

${ }^{a}$ Whole-crop corn forage was treated at ensiling either with distilled water (2 L/t; untreated) or with Lactobacillus plantarum MA 18/5U at $1 \times 10^{5} \mathrm{cfu} / \mathrm{g}$ fresh forage (Lallemand Animal Nutrition, Goiânia, GO, Brazil) and Bacillus subtilis AT553098 at $1 \times 10^{5} \mathrm{cfu} / \mathrm{g}$ fresh forage (inoculated; Fatec Animal Nutrition and Health, Arujá, SP, Brazil).

b The $\alpha$-amylase (602 DU/kg DM) was supplied to the wethers at total mixed ration delivery.

${ }^{\mathrm{c}} \mathrm{I}=$ inoculation; $\mathrm{E}=$ amylase; $\mathrm{I} \times \mathrm{E}=$ interaction between inoculation and amylolytic enzyme; $\mathrm{T}=$ sampling time; $\mathrm{I} \times \mathrm{E} \times \mathrm{T}=$ interaction among inoculation, amylolytic enzyme, and sampling time.

${ }^{\mathrm{d}} \mathrm{VFA}=$ volatile fatty acids.

propionic acid and acetic: propionic ratio was affected by the interaction between inoculation and enzyme supply; enzyme supply increased propionic acid $(P=0.002)$ and decreased acetic: propionic ratio $(P=0.005)$ when the wethers were fed the US diet, but not when they were fed the IS diet. Ruminal $\mathrm{pH}$, ammonia-N, and total VFA were unaffected by inoculation $(P=0.23)$, enzyme supply $(P=0.25)$, or their interaction $(P=0.23)$. 
Ruminal $\mathrm{pH}$, ammonia-N, total VFA production, molar proportions of acetic, propionic, and butyric acids, and the acetic: propionic ratio were affected by the time post feeding $(P<0.001$; Table 4$)$. Ruminal pH dropped from 6.5 to 5.5 after $12 \mathrm{~h}$ post feeding (Fig. 1a). Ammonia-N peaked at 3 and $9 \mathrm{~h}$ post feeding (27.4 and $27.9 \mathrm{mg} / \mathrm{dL}$, respectively; Fig. 1b). Total VFA increased from 59.8 to $91.7 \mathrm{mM}$ after $12 \mathrm{~h}$ post feeding (Fig. 1c). The molar proportion of acetic acid decreased $(70.8$ to $65.0 \mathrm{mM} / 100 \mathrm{mM}$ after $12 \mathrm{~h}$ post feeding) while propionic acid increased ( 17.3 to $23.4 \mathrm{mM} / 100 \mathrm{mM}$ after $12 \mathrm{~h}$ post feeding) with time post feeding (Fig. $2 \mathrm{a}$ and b). The molar proportion of butyric acid decreased up to $6 \mathrm{~h}$ post feeding, but increased thereafter (Fig. 2c). The acetic: propionic ratio decreased with the time post feeding (4.2 to 2.7 after $12 \mathrm{~h}$; Fig. $2 \mathrm{~d}$ ).

\subsection{Microbial $N$ synthesis and $N$ balance}

Enzyme supply tended $(P=0.074)$ to increase the DOMR in wethers fed the US diet, but not in those fed the IS diet (Table 5). Moreover, there was an interaction between inoculation and enzyme supply for microbial N supply; enzyme supply decreased microbial N supply $(P=0.025)$ when the wethers were fed the IS diet, but not the US diet. Conversely, neither inoculation $(P=0.32)$, nor enzyme supply $(P=0.36)$ or their interaction $(P=0.36)$ altered EMNS.

There was an interaction between inoculation and enzyme supply for fecal $\mathrm{N}$, in which enzyme supply decreased fecal $\mathrm{N}(P<$ 0.001 ) when the wethers were fed the IS diet, but not in those fed the US diet (Table 5). However, neither inoculation $(P=0.86)$, nor
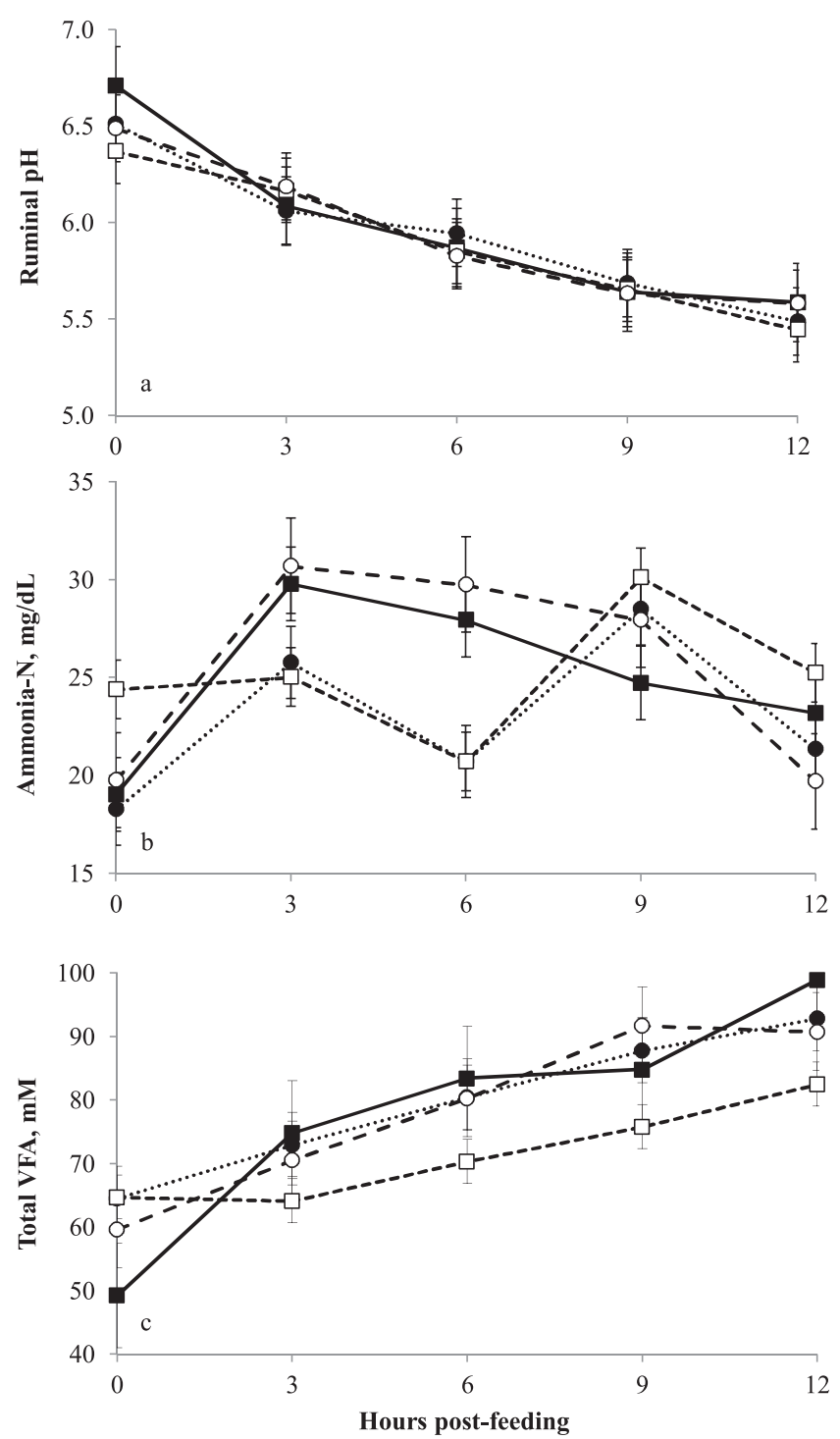

Fig. 1. Values of $\mathrm{pH}$ (a), ammonia-N (b), and total VFA (c) in the ruminal fluid at different intervals post feeding of wethers consuming 1) corn silage untreated (US) without amylolytic enzyme (NE; $\mathbf{0}$ ), 2) US with amylolytic enzyme supply at feeding (WE; @), 3) corn silage inoculated with Lactobacillus plantarum and Bacillus subtilis (IS) and NE ( $\square$ ), and 4) IS-WE (O). 

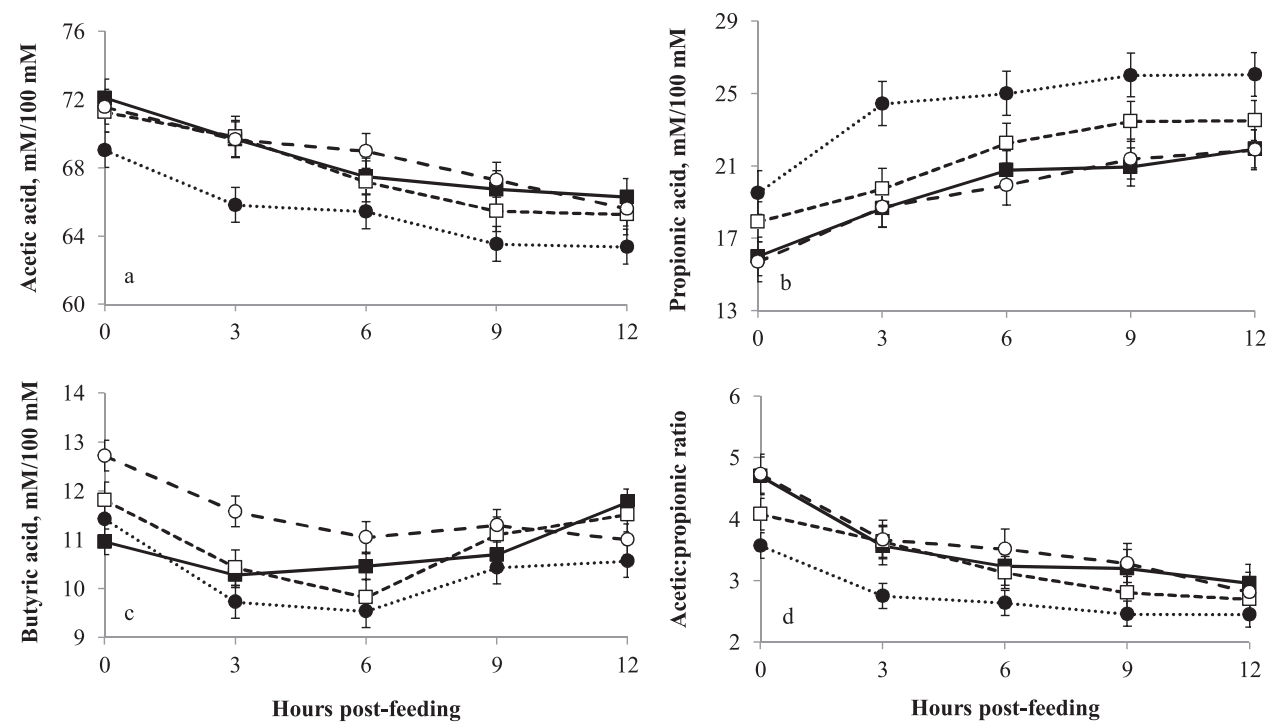

Fig. 2. Overall mean of molar proportions of acetic acid (a), propionic acid (b), and butyric acid (c) and acetic: propionic ratio (d) in the ruminal fluid at different intervals post feeding of wethers consuming 1) corn silage untreated (US) without amylolytic enzyme (NE; $\square$ ), 2) US with amylolytic enzyme supply at feeding (WE; ๑), 3) corn silage inoculated with Lactobacillus plantarum and Bacillus subtilis (IS) and NE ( $\square$ ), and 4) ISWE (O).

Table 5

Microbial protein synthesis and $\mathrm{N}$ balance in wethers fed diets containing corn silage untreated (US) or inoculated with Lactobacillus plantarum and Bacillus subtilis (IS) associated with (WE) or without amylolytic enzyme (NE) supply at feeding*.

\begin{tabular}{|c|c|c|c|c|c|c|c|c|}
\hline \multirow{2}{*}{$\begin{array}{l}\text { Inoculation }^{\mathrm{a}} \\
\text { Enzyme }^{\mathrm{b}}\end{array}$} & \multicolumn{2}{|l|}{ US } & \multicolumn{2}{|l|}{ IS } & \multirow[t]{2}{*}{ SEM } & \multicolumn{3}{|c|}{$P$-value ${ }^{c}$} \\
\hline & $\mathrm{NE}$ & WE & NE & WE & & I & $\mathrm{E}$ & $\mathrm{I} \times \mathrm{E}$ \\
\hline \multicolumn{9}{|l|}{ Microbial N synthesis, g/d } \\
\hline DOMR $^{\mathrm{d}}$ & 324 & 409 & 400 & 378 & 17.3 & 0.434 & 0.275 & 0.074 \\
\hline Microbial N supply & $7.01^{x y}$ & $8.01^{\mathrm{x}}$ & $8.05^{\mathrm{x}}$ & $6.33^{\mathrm{y}}$ & 0.30 & 0.571 & 0.522 & 0.025 \\
\hline EMNS, kg DOMR & 20.9 & 20.9 & 20.7 & 17.0 & 1.00 & 0.317 & 0.364 & 0.363 \\
\hline \multicolumn{9}{|l|}{$\mathrm{N}$ utilization, $\mathrm{g} / \mathrm{d}$} \\
\hline $\mathrm{N}$ intake & 29.0 & 32.5 & 31.1 & 27.9 & 1.14 & 0.526 & 0.935 & 0.102 \\
\hline Urinary $\mathrm{N}$ & 7.27 & 7.98 & 7.68 & 6.51 & 0.42 & 0.501 & 0.765 & 0.239 \\
\hline Fecal N & $8.89^{x}$ & $9.96^{\mathrm{x}}$ & $9.63^{x}$ & $6.42^{\mathrm{y}}$ & 0.52 & 0.013 & 0.049 & $<0.001$ \\
\hline $\mathrm{N}$ absorbed & 19.7 & 22.5 & 21.5 & 21.4 & 0.84 & 0.855 & 0.404 & 0.396 \\
\hline $\mathrm{N}$ retained & 13.8 & 14.6 & 13.8 & 14.8 & 0.85 & 0.954 & 0.567 & 0.924 \\
\hline $\mathrm{N}$ retained: $\mathrm{N}$ intake & 0.45 & 0.43 & 0.44 & 0.53 & 1.95 & 0.195 & 0.265 & 0.143 \\
\hline $\mathrm{N}$ retained: $\mathrm{N}$ absorbed & 0.65 & 0.63 & 0.64 & 0.68 & 2.15 & 0.605 & 0.828 & 0.349 \\
\hline
\end{tabular}

${ }^{\mathrm{x}-\mathrm{y}}$ Means in the same row with different superscripts differed significantly $(P \leq 0.05)$.

* Measurements were taken on days 11-15 of each period.

${ }^{a}$ Whole-crop corn forage was treated at ensiling either with distilled water (2 L/t; untreated) or with Lactobacillus plantarum MA 18/5U at $1 \times 10^{5} \mathrm{cfu} / \mathrm{g}$ fresh forage (Lallemand Animal Nutrition, Goiânia, GO, Brazil) and Bacillus subtilis AT553098 at $1 \times 10^{5} \mathrm{cfu} / \mathrm{g}$ fresh forage (inoculated; Fatec Animal Nutrition and Health, Arujá, SP, Brazil).

b The $\alpha$-amylase (602 DU/kg DM) was supplied to the wethers at total mixed ration delivery.

${ }^{\text {c }}$ I = inoculation; $\mathrm{E}=$ amylolytic enzyme; $\mathrm{I} \times \mathrm{E}=$ interaction between inoculation and amylolytic enzyme.

${ }^{\mathrm{d}}$ DOMR $=$ digestible organic matter fermented in the rumen; EMNS $=$ efficiency of microbial $\mathrm{N}$ synthesis.

enzyme supply $(P=0.40)$ or their interaction $(P=0.40)$ altered the $\mathrm{N}$ absorbed and retained.

\section{Discussion}

Statistical analysis regarding the effect of bacterial inoculation on fermentation and chemical composition of corn silage was precluded because the lack of farm-scale silo replicates $(n=1)$. Anyway, a brief description and discussion about silage quality is needed because corn silage comprised part of the diets and treatments (inoculation) investigated in this study. The chemical composition of corn silage used in the present study was typical of those produced in tropical areas (Arriola et al., 2001; Fugita et al., 2012; Lara et al., 2016). Despite the inoculation, lactic acid content was below the normal range reported for corn silage (40-70 $\mathrm{g} / \mathrm{kg}$ 
DM; Kung and Shaver, 2001). Corn silage was sampled during feed-out in this study, and likely the low content of lactic acid arises from its consumption by undesirable microorganisms such as yeasts while corn silage was liable to aerobic deterioration. Yeasts are able to use lactic acid as substrate to grow under aerobic exposure and they are fairly active in hot-climate environments (Adesogan, 2014; Ashbell et al., 2002).

Dietary supplementation with amylolytic enzyme has been used in order to improve feed utilization and is a strategy of interest for livestock production chain. In this regard, results of this study revealed that amylolytic enzyme supply increased DMI in wethers fed the US diet, but not in those fed the IS diet. This is likely due to the enhanced feed digestibility caused by enzyme supply. Previous studies reported that feed strategies and management enhancing dietary digestibility may increase passage rate, and therefore, DMI is also increased (Blaxter and Wilson, 1962; Mertens, 2010). Because of the increased DMI, wethers fed the US-WE diet also had higher starch intake and there was a tendency towards increased OM, aNDFom, GE, DE, and ME intake in comparison with those fed the USNE diet. Conversely, the reason underlying the lack of positive results from amylolytic enzyme supply on the DMI of wethers fed the IS diet might be attributable to differences in ingredient composition between the diets, since inoculation of corn silage with L. plantarum and B. subtilis yielded some differences in silage composition and fermentation end products. Indeed, the interaction between $\alpha$-amylase supplementation and corn silage inoculation for DMI suggests that improvements on animal production following $\alpha$-amylase supplementation might be dependent of dietary composition and fermentation process of silage within the silo when this feedstuff is added to the diet. Nevertheless, this is not totally clear and further investigation is needed to understand why enzyme supply elicited different responses on DMI of lambs depending whether silage inoculation occurred or not. Anyway, the expected impact of dietary supplementation with an amylolytic enzyme as a direct-feed additive on the DMI of small and large ruminants is difficult to envision because previous studies variously reported increased DMI (Klingerman et al., 2009; Tricarico et al., 2007), no effect (DeFrain et al., 2005; Nozière et al., 2014), and decreased DMI (Rojo et al., 2005).

Despite the inconsistent effects of enzyme supply on DMI, the coefficients of apparent digestibility of DM, OM, CP, aNDFom, and GE were improved by $5.1 \%, 4.7 \%, 9.4 \%, 20.7 \%$, and $6.2 \%$, respectively, regardless of the corn silage fed. Even though the amylolytic enzyme supply has been used to improve dietary starch utilization (Tricarico et al., 2008), no alteration of starch digestibility was observed in the current study. The causes for the lack of responses on the gastrointestinal tract digestibility have been previously discussed by Gencoglu et al. (2010). Otherwise, the increased digestibility observed for feed components other than starch, is in accordance with the literature (Klingerman et al., 2009; Takiya et al., 2017). According to Beauchemin et al. (2004), increasing enzymatic activity in the rumen by exogenous enzyme supplementation can increase the ruminal hydrolytic capacity, enhancing the digestibility of all dietary components, rather than acting just on the specific targets of enzymes. Furthermore, enhanced feed digestion may arise from cross-feeding mechanisms that are a general feature of the ruminal microbial ecosystem (Tricarico et al., 2008). According to these authors, exogenous enzymes hydrolyze complex carbohydrates into oligosaccharides leading increased substrate availability due to exposition of 1) new sites for hydrolytic attack in the polymer by polymer-degrading bacteria, and 2) oligosaccharides for cross-feeding by microbes that would not normally have access to it. The increased substrate availability may explain the enhanced digestion following dietary enzyme supply, and thereby supporting the cross-feeding hypothesis in the rumen (Tricarico et al., 2008). The results of the current study are in agreement with those of Chen et al. (1995) and Klingerman et al. (2009), who reported no effect of amylase supplied alone or combined with protease on starch digestibility, but found increased OM, $\mathrm{CP}$, and NDF digestibility.

Even though bacterial inoculants have been used mostly to improve silage fermentation, some reviews reported benefits of inoculation on silage utilization by ruminants (Oliveira et al., 2017; Rabelo et al., 2016b). In this regard, our study showed that inoculation of corn silage with L. plantarum and B. subtilis improved OM, CP, aNDFom, and GE digestibility by 5.3\%, 11.5\%, 25.8\%, and $7.1 \%$, respectively. These results likely arise from an increased DM recovery with more digestible nutrients following silage inoculation. Even though DM recovery was not measured in this study, the application of bacterial inoculant increased lactic acid content and resulted in higher preservation of NFC of corn silage, and a homolactic fermentation profile often results in higher DM recovery (Oliveira et al., 2017; Santos et al., 2013). Furthermore, the homolactic inoculation (i.e., L. plantarum) is used to inhibit spoilage and pathogenic microbes through reducing silage $\mathrm{pH}$ rapidly, thereby preserving the nutritional value of the ensiled forage (McDonald et al., 1991), with gains in silage digestibility (Lara et al., 2016). Notably, enhanced silage digestibility following bacterial inoculation has been reported in some cases, but in lower frequency than alterations in silage fermentation (Weinberg and Muck, 1996). For instance, our results agree in part with the results of Rabelo et al. (2016b), who, in a review of 19 studies on sheep, reported that inoculation of corn silage increased CP digestibility in $20 \%(+9.1 \%$ in comparison with the untreated silage) of the studies, but the other dietary components remained unaltered. Moreover, it is worth nothing that the utilization of $B$. subtilis as a silage inoculant to improve silage quality and livestock production is not a common practice, although previous studies had reported potential for it (Basso et al., 2012; Lara et al., 2016); perhaps the reason behind that arises from the toxigenic potential of $B$. subtilis (Beattie and Williams, 1999). However, previous studies administrating B. subtilis as a direct-fed microbial or silage inoculant into the diets of calves, beef cattle, and dairy cows reported no problem regarding feed intake, growth performance, and quality of beef meat and milk produced (Rabelo et al., 2018; Sun et al., 2010, 2013). Thus, based on the literature is unlikely that using B. subtilis as a silage inoculant could cause any problem on livestock health.

Inoculation of corn silage and amylolytic enzyme supply did not affect ruminal $\mathrm{pH}$, ammonia-N, or total VFA production. This result is in accordance with previous studies in which little or no effect of inoculation (Rabelo et al., 2018) and dietary supplementation with $\alpha$-amylase was reported on ruminal fermentation (DeFrain et al., 2005; Takiya et al., 2017). Conversely, although the treatments investigated did not alter total VFA production, they altered the molar proportion of VFA. Inoculation increased the molar proportion of acetic acid only when wethers were fed the WE diet. This result likely arises from the enhanced aNDFom digestibility found in the IS-WE diet. Increased molar proportion of acetic acid is related to the increased activity of fiber-fermenting bacteria in 
the rumen, which is well documented in the literature (Russell, 1998). Furthermore, dietary supplementation with an amylolytic enzyme increased the molar proportion of propionic acid in wethers fed the US diet. This result may be attributed to the higher starch intake observed in the US-WE diet than with the US-NE diet. Propionate is often increased by the higher activity of starch-fermenting bacteria in cases in which the intake of starch and NFC is high (Russell, 1998). As a consequence of the increased molar proportion of propionic acid, the acetic: propionic ratio in the rumen of wethers fed the US-WE diet was reduced. Our results are in accordance with those of Nozière et al. (2014), with respect to total VFA production, but they reported an increased molar proportion of propionic acid and decreased acetic acid following amylase supplementation.

Dietary supplementation with amylolytic enzyme tended to increase the DOMR in wethers fed the US diet, but not for the IS diet. This response likely arises from the increased OM intake observed in wethers fed the US-WE diet in comparison with that in those fed the US-NE diet, as DOMR and OM intake are positively related (Clark et al., 1992). Moreover, despite the increased DMI and DE intake observed with the US-WE diet compared to that with the US-NE diet, amylolytic enzyme supply did not alter microbial N synthesis. However, surprisingly enzyme supply decreased microbial $\mathrm{N}$ synthesis when the wethers were fed the IS diet. Ensiling process might result in increased CP solubility and VFA production within the silo; this reduces protein utilization in the rumen resulting in lower microbial protein synthesis (Charmley, 2001). Although CP solubility was not measured in this study, inoculated corn silage had higher ammonia-N concentration, which could indicate higher proteolysis within the silo leading a lower microbial $\mathrm{N}$ synthesis in wethers fed the IS diets. Nonetheless, this was observed only in the IS-WE diet, likely due to differences in OM and CP digestibility following $\alpha$-amylase supplementation with its cross-feeding effect in the rumen (Tricarico et al., 2008), so that energy/ protein synchronization was not met to favor microbial N synthesis in the rumen (Sinclair et al., 1993). However, this is not totally clear since microbial $\mathrm{N}$ synthesis can be affected by animal age and physiology, dietary composition, $\mathrm{N}$ and energy supply, rumen outflow rate, and rumen environment remarkably affects microbial N synthesis (Verbič, 2002). Lastly, the EMNS was unaffected by either inoculation or amylolytic enzyme supply, but the values obtained in the current study are in agreement with those of the ARC (1984. Our results are supported by those of Nozière et al. (2014), who found increased ruminal digestibility of OM, but no effect of dietary supplementation with amylase on the microbial $\mathrm{N}$ flow to the duodenum in lactating dairy cows.

Dietary supplementation with amylolytic enzyme decreased the $\mathrm{N}$ fecal only in wethers fed the IS diet; however, $\mathrm{N}$ absorbed and retained were unaltered. A meta-analytical study showed there is a linear relationship between $\mathrm{N}$ retention and $\mathrm{N}$ intake for sheep (Schuba et al., 2017). Thus, as inoculation and amylolytic enzyme supply did not alter $\mathrm{N}$ intake in the current study, we could expect a similar $\mathrm{N}$ retention and absorption. Our results are in agreement with those of Takiya et al. (2017), who reported no effect of increasing dietary doses of an $A$. oryzae extract with $\alpha$-amylase activity on the $\mathrm{N}$ utilization in lactating dairy cows fed TMR composed of corn silage.

In summary, our study combined with previous results from the literature (Klingerman et al., 2009; Nozière et al., 2014; Tricarico et al., 2008) revealed there is an inconsistent effect of dietary supplementation with amylolytic enzyme on feed intake, digestion, and microbial protein synthesis. The causes for such inconsistencies might arise from differences in 1) dietary composition and dosage of enzyme (Klingerman et al., 2009; Tricarico et al., 2008), 2) source of enzyme (i.e., A. oryzae, A. niger, and Bacillus licheniformis; Rojo et al., 2005; Tricarico et al., 2008), 3) formulation of enzyme (i.e., batch preparations vs. commercial products; Klingerman et al., 2009), and 4) conditions of temperature and pH and enzymatic activity (Colombatto and Beauchemin, 2003; Klingerman et al., 2009; van der Maarel et al., 2002). Moreover, studies carried out under similar conditions have also shown inconsistent results. For example, the dietary supplementation with amylolytic enzyme increased the ADF intake and tended towards increased intakes of DM, $\mathrm{OM}$, and NDF in Angus and Angus-crossbred steers fed dry-rolled corn-based finishing diets, but no improvements were reported for steers fed steam-flaked corn-based finishing diets (DiLorenzo et al., 2011). In this regard, animal breed, age and physiology seem to affect the response of amylolytic enzyme supply, but the mechanisms by which this occurs is unknown and should be investigated further.

\section{Conclusions}

Dietary supplementation with amylolytic enzyme inconsistently improved the feed intake of wethers fed diets differing in the use of silage inoculant. Inoculation of corn silage and amylolytic enzyme supply consistently improved OM digestibility, but their interaction decreased microbial protein synthesis. Therefore, according to the experimental conditions of this study, feeding wethers with corn silage inoculated with $L$. plantarum and B. subtilis associated with amylolytic enzyme supply is not recommended.

\section{Conflict of interest}

The authors declare there is no conflict of interest.

\section{Acknowledgements}

The authors wish to thank the "Conselho Nacional de Desenvolvimento Científico e Tecnológico" (CNPq grant \#141008/2014-8) for its financial support. Bacteria provided for this study from Lallemand Animal Nutrition and Fatec Animal Nutrition and Health are gratefully acknowledged. We would like to thank Nutreco and Alltech for providing respectively the concentrate and $\alpha$-amylase for this study. 


\section{References}

Adesogan, A.T., 2014. Avoiding the two greatest silage problems. Proceedings of the 50th Florida Dairy Production Conference. University of Florida, Gainesville, FL, pp. 9-17.

AOAC, 1996. Official Methods of Analysis, 16 ed. AOAC, Washington DC, USA.

ARC, 1984. The Nutrient Requirements of Ruminant Livestock. Commonwealth Agricultural Bureau, Farnham Royal, UK.

Arriola, K.G., Kim, S.C., Staples, C.R., Adesogan, A.T., 2001. Effect of applying bacterial inoculants containing different types of bacteria to corn silage on the performance of dairy cattle. J. Dairy Sci. 94, 3973-3979.

Ashbell, G., Weinberg, Z.G., Hen, Y., Filya, I., 2002. The effects of temperature on the aerobic stability of wheat and corn silages. J. Ind. Microbiol. Biotechnol. 28, 261-263.

Bach Knudsen, K.E., Eggum, B.O., Jacobsen, I., 1987. Nutritive-value of Danish-grown barley varieties. Carbohydrates and other major constituents. J. Cereal Sci. 6, $173-186$.

Basso, F.C., Lara, E.C., Assis, F.B., Rabelo, C.H.S., Morelli, M., Reis, R.A., 2012. Características da fermentação e estabilidade aeróbia de silagens de milho inoculadas com Bacillus subtilis. Rev. Bras. Saúde Prod. Anim. 13, 1009-1019.

Basso, F.C., Adesogan, A.T., Lara, E.C., Rabelo, C.H.S., Berchielli, T.T., Teixeira, I.A.M.A., Siqueira, G.R., Reis, R.A., 2014. Effects of feeding corn silage inoculated with microbial additives on the ruminal fermentation, microbial protein yield, and growth performance of lambs. J. Anim. Sci. 92, 5640-5650.

Beattie, S.H., Williams, A.G., 1999. Detection of toxigenic strains of Bacillus cereus and other Bacillus spp. with an improved cytotoxicity assay. Lett. Appl. Microbiol. 28, 221-225.

Beauchemin, K.A., Colombatto, D., Morgavi, D.P., Yang, W.Z., Rode, L.M., 2004. Mode of action of exogenous cell wall degrading enzymes for ruminants. Can. J. Anim. Sci. 84, 13-22.

Bernardes, T.F., Rêgo, A.C., 2014. Study on the practices of silage production and utilization on Brazilian dairy farms. J. Dairy Sci. 97, 1852-1861.

Blaxter, K.L., Wilson, R.S., 1962. The voluntary intake of roughages by steers. Anim. Prod. 4, 351-358.

Charmley, E., 2001. Towards improved silage quality - a review. Can. J. Anim. Sci. 81, 157-168.

Chen, X.B., Gomes, M.J., 1995. Estimation of Microbial Protein Supply to Sheep and Cattle Based on Urinary Excretion of Purine Derivatives - An Overview of the Technical Details. Occasional Publication. Rowett Research Institute, Bucksburn, Aberdeen, UK.

Chen, K.H., Huber, J.T., Simas, J., Theurer, C.B., Yu, P., Chan, S.C., Santos, F., Wu, Z., Swingle, R.S., DePeters, E.J., 1995. Effect of enzyme treatment or steam-flaking of sorghum grain on lactation and digestion in dairy cows. J. Dairy Sci. 78, 1721-1727.

Clark, J.H., Klusmeyer, T.H., Cameron, M.R., 1992. Microbial protein synthesis and flows of nitrogen fractions to the duodenum of dairy cows. J. Dairy Sci. 75, 2304-2323.

Colombatto, D., Beauchemin, K.A., 2003. A proposed methodology to standardize the determination of enzymic activities present in enzyme additives used in ruminant diets. Can. J. Anim. Sci. 83, 559-568.

DeFrain, J.M., Hippen, A.R., Kalscheur, K.F., Tricarico, J.M., 2005. Effects of dietary alpha amylase on metabolism and performance of transition dairy cows. J. Dairy Sci. 88, 4405-4413.

Detmann, E., Valadares Filho, S.C., 2010. On the estimation of non-fibrous carbohydrates in feeds and diets. Arq. Bras. Med. Vet. Zootec. 62, $980-984$.

DiLorenzo, N., Smith, D.R., Quinn, M.J., May, M.L., Ponce, C.H., Steinberg, W., Engstrom, M.A., Galyean, M.L., 2011. Effects of grain processing and supplementation with exogenous amylase on nutrient digestibility in feedlot diets. Liv. Sci. 137, 178-184.

Fenner, H., 1965. Method for determining total volatile bases in rumen fluid by stem distillation. J. Dairy Sci. 48, $249-251$.

Food Chemicals Codex, 1996. 4th ed. Natl. Acad. Press, Washington, DC.

Fugita, C.A., Prado, I.N., Jobim, C.C., Zawadzki, F., Valero, M.V., Pires, M.C.O., Prado, R.M., Françozo, M.C., 2012. Corn silage with and without enzyme-bacteria inoculants on performance, carcass characteristics and meat quality in feedlot finished crossbred bulls. R. Bras. Zootec. 41, 154-163.

Gencoglu, H., Shaver, R.D., Steinberg, W., Ensink, J., Ferraretto, L.F., Bertics, S.J., Lopes, J.C., Akins, M.S., 2010. Effect of feeding a reduced-starch diet with or without amylase addition on lactation performance in dairy cows. J. Dairy Sci. 93, 723-732.

Klingerman, C.M., Hu, W., McDonell, E.E., Der Bedrosian, M.C., Kung Jr., L., 2009. An evaluation of exogenous enzymes with amylolytic activity for dairy cows. J. Dairy Sci. 92, 1050-1059.

Kung Jr., L., Shaver, R., 2001. Interpretation and use of silage fermentation analysis reports. Focus For. 3, 1-5.

Lara, E.C., Basso, F.C., Assis, F.B., Souza, F.A., Berchielli, T.T., Reis, R.A., 2016. Changes in the nutritive value and aerobic stability of corn silages inoculated with Bacillus subtilis alone or combined with Lactobacillus plantarum. Anim. Prod. Sci. 56, 1867-1874.

McDonald, P., Henderson, A.R., Heron, S.J.E., 1991. The Biochemistry of Silage, 2nd ed. Chalcombe Publications, Abersytwyth, UK.

Mertens, D.R., 2002. Gravimetric determination of amylase treated neutral detergent fiber in feeds with refluxing in beakers or crucibles: collaborative study. J. AOAC Int. 85, 1212-1240.

Mertens, D.R., 2010. Syracuse, NY. NDF and DMI-has Anything Changed? Proc. Cornell Nutr. Conf. 160-174.

Mohammadzadeh, H., Khorvash, M., Ghorbani, G.R., Yang, W.Z., 2012. Frosted corn silage with or without bacterial inoculants in dairy cattle ration. Liv. Sci. 145, $153-159$.

Noziére, P., Steinberg, W., Silberberg, M., Morgavi, D.P., 2014. Amylase addition increases starch ruminal digestion in first-lactation cows fed high and low starch diets. J. Dairy Sci. 97, 2319-2328.

NRC, 1985. Nutrient Requirements of Sheep. Natl. Acad. Press, Washington, DC, USA.

NRC, 2007. Nutrient Requirements of Small Ruminants: Sheep, Goats, Cervids, and New World Camelids. Natl. Acad. Press, Washington, DC, USA.

Oliveira, C.A., Millen, D.D., 2014. Survey of the nutritional recommendations and management practices adopted by feedlot cattle nutritionists in Brazil. Anim. Feed Sci. Technol. 197, 64-75.

Oliveira, A.S., Weinberg, Z.G., Ogunade, I.M., Cervantes, A.A.P., Arriola, K.G., Jiang, Y., Kim, D., Li, X., Gonçalves, M.C.M., Vyas, D., Adesogan, A.T., 2017. Metaanalysis of effects of inoculation with homofermentative and facultative heterofermentative lactic acid bacteria on silage fermentation, aerobic stability, and the performance of dairy cows. J. Dairy Sci. 100, 4587-4603.

Pryce, J.D., 1969. A modification of the Barker-Summerson method for the determination of lactic acid. Analyst 94, 1151-1152.

Rabelo, C.H.S., Basso, F.C., McAllister, T.A., Lage, J.F., Gonçalves, G.S., Lara, E.C., Oliveira, A.A., Berchielli, T.T., Reis, R.A., 2016a. Influence of Lactobacillus buchneri as silage additive and forage:concentrate ratio on the growth performance, fatty acid profile in longissimus muscle and meat quality of beef cattle. Can. J. Anim. Sci. 96, 550-562.

Rabelo, C.H.S., Mari, L.J., Reis, R.A., 2016b. Survey about the use of bacterial inoculants in Brazil: effects on silage quality and animal performance. In: Silva, T., Santos, E.M. (Eds.), Advances in Silage Production and Utilization. InTech, Rijeka, Croatia, pp. 3-37.

Rabelo, C.H.S., Basso, F.C., Lara, E.C., Jorge, L.G.O., Härter, C.J., Mari, L.J., Reis, R.A., 2017. Effects of Lactobacillus buchneri as a silage inoculant or probiotic on in vitro organic matter digestibility, gas production, and volatile fatty acids of low dry matter whole-crop maize silage. Grass For. Sci. 1-11. http://dx.doi.org/10. $1111 /$ gfs. 12273.

Rabelo, C.H.S., Valente, A.L.S., Barbero, R.P., Basso, F.C., Reis, R.A., 2018. Performance of finishing beef cattle fed diets containing maize silages inoculated with lactic-acid bacteria and Bacillus subtilis. Anim. Prod. Sci. http://dx.doi.org/10.1071/AN16358.

Rode, L.M., McAllister, T.A., Beauchemin, K.A., Morgavi, D.P., Nsereko, V.L., Yang, W.Z., Iwaasa, A.D., Wang, Y., 2001. Enzymes as direct-feed additives for ruminants. Biotechnology in Animal Husbandry. Springer, Netherlands, pp. 301-332.

Rojo, R., Mendoza, G.D., Gonzalez, S.S., Landois, L., Barcena, R., Crosby, M.M., 2005. Effects of exogenous amylases from Bacillus licheniformis and Aspergillus niger on ruminal starch digestion and lamb performance. Anim. Feed Sci. Technol. 124, 655-665.

Russell, J.B., 1998. The importance of pH in the regulation of ruminal acetate to propionate ratio and methane production in vitro. J. Dairy Sci. 81, 3222-3230.

Santos, A.O., Ávila, C.L.S., Schwan, R.F., 2013. Selection of tropical lactic acid bacteria for enhancing the quality of maize silage. J. Dairy Sci. 96, 7777-7789. 
Schuba, J., Südekum, K.-H., Pfeffer, E., Jayanegara, A., 2017. Excretion of faecal, urinary urea and urinary non-urea nitrogen by four ruminant species as influenced by dietary nitrogen intake: a meta-analysis. Liv. Sci. 198, 82-88.

Sinclair, L.A., Arnsworth, P.C.G., Newbold, J.R., Buttery, P.J., 1993. Effect of synchronizing the rate of dietary energy and nitrogen release on rumen fermentation and microbial protein synthesis in sheep. J. Agric. Sci. 120, 251-263.

Sniffen, C.J., O'Connor, J.D., van Soest, P.J., Fox, D.G., Russell, J.B., 1992. A net carbohydrate and protein system for evaluating cattle diets: II. Carbohydrate and protein availability. J. Anim. Sci. 70, 3562-3577.

Sun, P., Wang, J.Q., Zhang, H.T., 2010. Effects of Bacillus subtilis natto on performance and immune function of preweaning calves. J. Dairy Sci. 93, 5851-5855.

Sun, P., Wang, J.Q., Deng, L.F., 2013. Effects of Bacillus subtilis natto on milk production, rumen fermentation and ruminal microbiome of dairy cows. Animal 7 , $216-222$.

Takiya, C.S., Calomeni, G.D., Silva, T.H., Vendramini, T.H.A., Silva, G.G., Consentini, C.E.C., Bertoni, J.C., Zilio, E.M.C., Rennó, F.P., 2017. Increasing dietary doses of an Aspergillus oryzae extract with alpha-amylase activity on nutrient digestibility and ruminal fermentation of lactating dairy cows. Anim. Feed Sci. Technol. 228, $159-167$.

Tricarico, J.M., Abney, M.D., Galyean, M.L., Rivera, J.D., Hanson, K.C., Mcleod, K.R., Harmon, D.L., 2007. Effects of a dietary Aspergillus oryzae extract containing alpha-amylase activity on performance and carcass characteristics of finishing beef cattle. J. Anim. Sci. 85, 802-811.

Tricarico, J.M., Johnston, J.D., Dawson, K., 2008. Dietary supplementation of ruminant diets with an Aspergillus oryzae $\alpha$-amylase. Anim. Feed Sci. Technol. 145, $136-150$.

van der Maarel, M.J.E.C., van der Veen, B., Uitdehaag, J.C.M., Leemhuis, H., Dijkhuizen, L., 2002. Properties and applications of starch-converting enzymes of the aamylase family. J. Biotechnol. 94, 137-155.

van Soest, P.J., Robertson, J.B., 1985. Analysis of Forages and Fibrous Foods. Cornell University, Ithaca, NY.

Verbič, J., 2002. Factors affecting microbial protein synthesis in the rumen with emphasis on diets containing forages. Milchproduktion Rindermast 29, 1-6.

Weinberg, Z.G., Muck, R.E., 1996. New trends and opportunities in the development and use of inoculants for silage. FEMS Microbiol. Rev. 19, 53-68. 